\title{
A PROPOSED MECHANISM FOR THE TRANSIENT SUPPRESSION OF BACTERIAL LUMINESCENCE BY HYDROGEN PEROXIDE
}

\author{
A. P. JACOBSON, L. R. PAPA and D. F. BRENDEL
}

Department of Environmental and Industrial Health, University of Michigan, Ann Arbor, Michigan 48104, U.S.A.

Received 15 June 1972

It has been shown previously that bacterial luminescence is reversibly suppressed in vivo and in vitro by both $\mathrm{X}$-rays and hydrogen peroxide. The data presented here show that the mechanism for this phenomenon is based on the transient oxidation of reduced flavin mononucleotide.

\section{Introduction}

It has been demonstrated that hydrogen peroxide $\left(\mathrm{H}_{2} \mathrm{O}_{2}\right)$ is formed in appreciable quantity by the action of ionizing radiations on oxygenated water ${ }^{1}$ ). Since living cells always contain and are usually bathed in high concentrations of water and adequate concentrations of oxygen, the conditions for production of $\mathrm{H}_{2} \mathrm{O}_{2}$ exist in most organisms during irradiation. However, successful attempts to demonstrate radiomimetic effects of $\mathrm{H}_{2} \mathrm{O}_{2}$ on living systems are $\mathrm{few}^{2}$ ).

Steady-state luminescence can be obtained easily from intact luminous bacteria (in vivo) or from cell-free extracts (in vitro). This biochemical homeostasis is immediately suppressed by X-rays. After irradiation, luminescence recovers promptly ${ }^{3}{ }^{4}$ ). Catalase protects the luminescent system from this effect ${ }^{5}$ ).

$\mathrm{H}_{2} \mathrm{O}_{2}$ has been found to mimic this reversible radiation effect in vivo ${ }^{5}$ ). Recently, we have shown that $\mathrm{H}_{2} \mathrm{O}_{2}$ also mimics radiation effects on luminescence in vitro ${ }^{6}$ ).

The data described in this paper provide the basis for an explanation of this transient suppression of bacterial luminescence produced both by X-rays and by $\mathrm{H}_{2} \mathrm{O}_{2}$.

\section{Background}

It has been shown that the reactions which produce bacterial luminescence 
are identical in vivo and in vitro ${ }^{7}$ ). All of the reactants are known. They are: reduced flavin mononucleotide $\left(\mathrm{FMNH}_{2}\right)$; molecular oxygen; a long-chain aliphatic aldehyde ( $\mathrm{RCHO}$ ); and the enzyme luciferase (L).

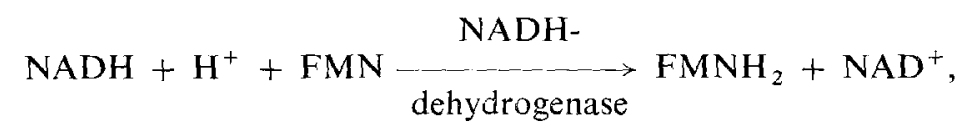

provides the substrate for luciferase. Luciferase reacts rapidly with $\mathrm{FMNH}_{2}$ to form a luciferase- $\mathrm{FMNH}_{2}$ intermediate. The latter adds molecular oxygen to form another intermediate, and this complex reacts with aldehyde. The aldehyde is oxidized to the corresponding acid, hydroxide is lost, and light is emitted from protonated flavin $\left.\left(\mathrm{FMNH}^{+}\right)^{9}\right)$.

Several points about reaction (1) are important to this study: in vivo, $\mathrm{NADH}$ is regenerated continuously by various nutrients ${ }^{7}$ ); in vitro, NADH is added to the extent that it is not rate limiting to the luminescent reactions ${ }^{4}$ ); bacterial luminescence in vivo and in vitro is a measure of both the amount of active luciferase and the steady-state concentration of $\mathrm{FMNH}_{2}{ }^{7}$ ); $\mathrm{FMNH}_{2}$ is extremely labile and readily oxidized by many agents including molecular oxygen ${ }^{10}$ ).

Many enzymes including luciferase are relatively radioresistant in vivo because they are literally bathed in molecules which protect them from free radicals and $\mathrm{H}_{2} \mathrm{O}_{2}{ }^{11}$ ). To mimic this protective effect of the cell's interior, we use bovine serum albumen (BSA) in vitro.

\section{Methods and materials}

\subsection{REAGENTS AND EQUIPMENT}

Except for NADH-dehydrogenase, all reagents were purchased from Sigma Chemical Co., St. Louis. NADH-dehydrogenase was isolated from Photobacterium fischeri and purified 145 fold $^{12}$ ). Hydrogen peroxide was assayed by the method of Kolthoff ${ }^{13}$ ).

A Gilford Model 240 spectrophotometer with Model 6040 strip chart recorder was used. Aerobic analyses were done with standard silica cuvettes. Anaerobic analyses were done with a gas-tight, dual side-arm cuvette.

\subsection{ASSAY}

Table 1 summarizes the composition of solutions used for aerobic and anaerobic assays.

\subsubsection{Aerobic analyses}

To study peroxide effects on NADH itself, NADH was dissolved in $0.1 \mathrm{M}$ phosphate buffer at pH 7.5. Bovine serum albumin (BSA), when used, was 


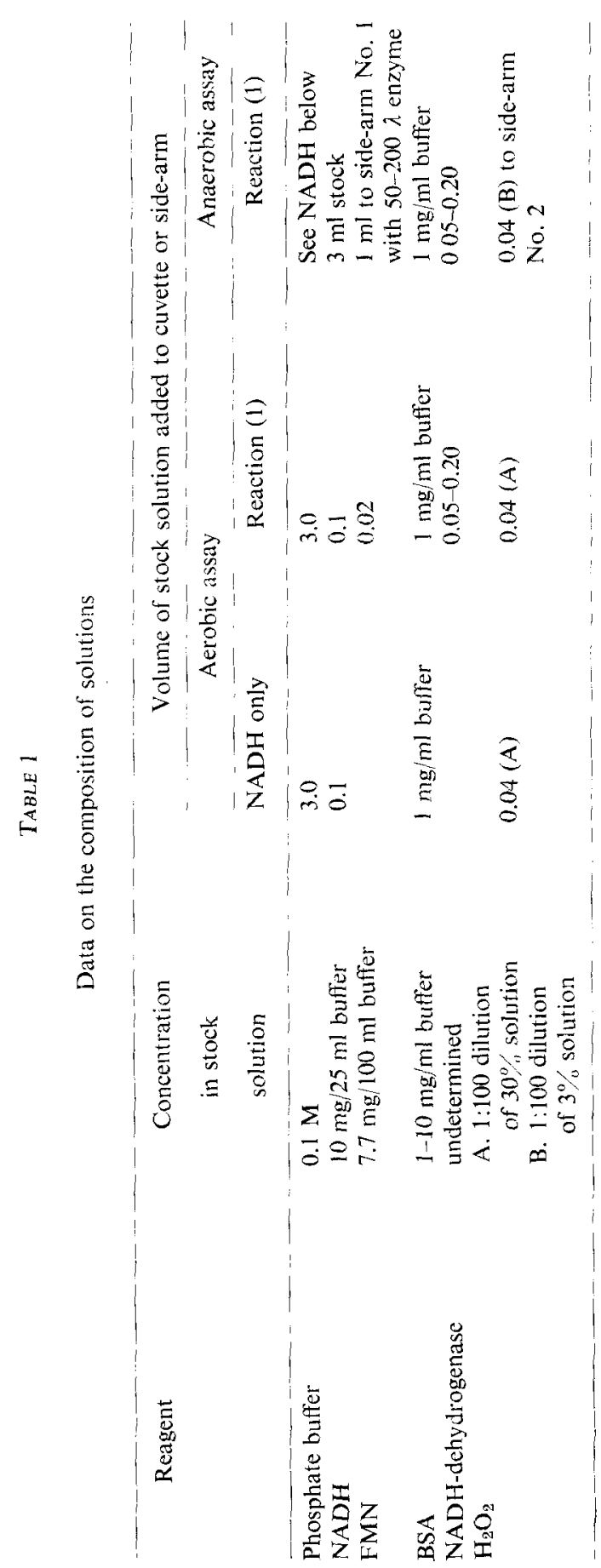


added to the buffer before experiments (table 1). Spectrophotometric measurements were made at $\mathrm{OD}_{340}$ before and after treatment with $\mathrm{H}_{2} \mathrm{O}_{2}$. For studies with the complete dehydrogenase reaction [reaction (1)] NADH, FMN, and NADH-dehydrogenase were suspended in buffer either with or without BSA (table 1). Oxidation of $\mathrm{NADH}$ was followed at $\mathrm{OD}_{340}$.

\subsubsection{Anaerobic analyses}

$\mathrm{FMNH}_{2}$ is rapidly oxidized by molecular oxygen nonenzymatically ${ }^{10}$ ). Measurements of $\mathrm{FMNH}_{2}$ formation by reaction (1) must be made anaerobically. For these measurements, the gas-tight cuvette was loaded with NADH in buffer. FMN and NADH-dehydrogenase were placed together in one side-arm; $\mathrm{H}_{2} \mathrm{O}_{2}$ in the other (table 1). This assembly was alternately evacuated at 20 in. of mercury and charged with prepurified $\mathrm{N}_{2}$ gas at 4 psig for a total of $60 \mathrm{~min}$. To ensure relatively complete anoxia and to rid the system of oxygen liberated by peroxide decomposition, small strips of agar with colonies of viable luminous bacteria were placed inside the cuvette above the solution before degassing. Either NADH or FMN $\left(\mathrm{OD}_{445}\right)$ can be measured anaerobically.

For both aerobic and anaerobic analyses, measurements were made before $\mathrm{H}_{2} \mathrm{O}_{2}$ treatment to ensure that no unexpected changes occurred. When freshly isolated NADH-dehydrogenase was used, some measure of its activity was obtained by measuring the rate of NADH oxidation before any peroxide treatment. Of course, dehydrogenase activity depends on its concentration in solution at the final stage of isolation. Thus, depending on this concentration, we added between $0.05-0.20 \mathrm{ml}$ in different experiments (table 1).

After peroxide treatments, all solutions were monitored long enough to ensure observation of all pertinent changes.

\section{Results}

\subsection{NADH}

Fig. 1 shows that NADH in phosphate buffer is readily oxidized by $9.3 \times 10^{-3} \mathrm{M} \mathrm{H}_{2} \mathrm{O}_{2}$ (solid triangles). However, in the presence of BSA, no appreciable oxidation of NADH occurs with similar amounts of peroxide (solid circles). Note that some decomposition of NADH occurs spontaneously (no peroxide, open circles).

Similar protection of NADH by BSA occurs in the presence of FMN and NADH-dehydrogenase. Fig. 1 shows that reaction (1) together with $1 \mathrm{mg}$ $\mathrm{ml}^{-1}$ BSA proceeds undisturbed by $9.3 \times 10^{-3} \mathrm{M} \mathrm{H}_{2} \mathrm{O}_{2}$ (open $\nabla$ ). Compare this with the same reaction without BSA ( $\square$ marks). 


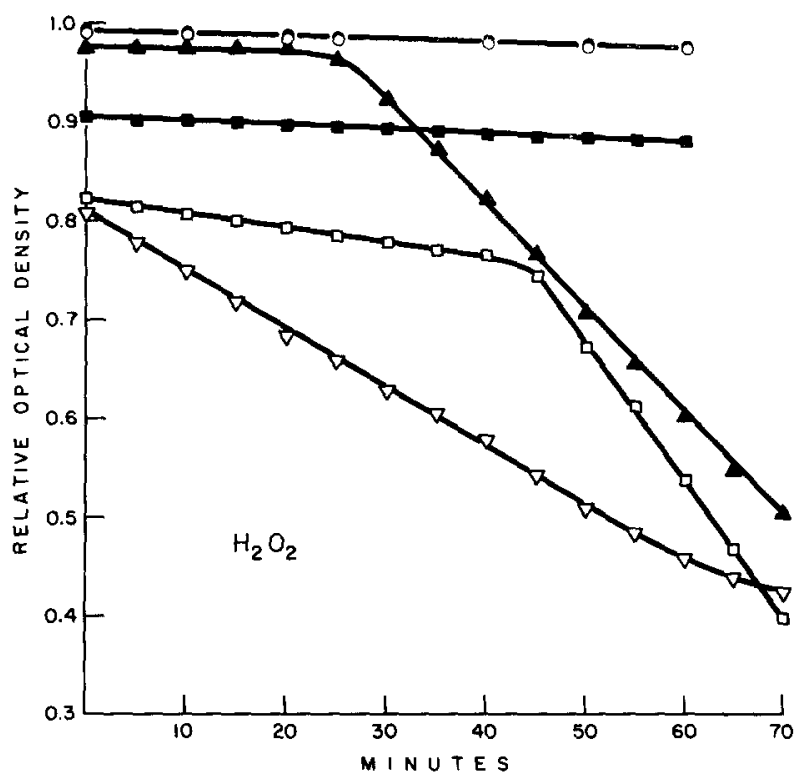

Fig. 1. The effects of $10^{-4} \mathrm{M} \mathrm{H}_{2} \mathrm{O}_{2}$ on NADH in phosphate buffer, $\mathrm{pH} 7.5$ with the following: $\bigcirc \mathrm{NADH}$ only, no $\mathrm{H}_{2} \mathrm{O}_{2}$ added, $-\mathrm{NADH}+\mathrm{BSA}\left(1 \mathrm{mg} \mathrm{ml}^{-1}\right), \mathrm{H}_{2} \mathrm{O}_{2}$ added at 22 min; $\triangle \mathrm{NADH}$ only, $\mathrm{H}_{2} \mathrm{O}_{2}$ added at $22 \mathrm{~min}$; NADH $+\mathrm{FMN}+\mathrm{BSA}\left(1 \mathrm{mg} \mathrm{ml}^{-1}\right)$ in phosphate buffer, $\mathrm{H}_{2} \mathrm{O}_{2}$ added at $43 \mathrm{~min} ; \square \mathrm{NADH}+\mathrm{FMN}+0.5 \mathrm{ml} \mathrm{NADH}$-dehydrogenase preparation, $\mathrm{H}_{2} \mathrm{O}_{2}$ added at $43 \mathrm{~min} ; \triangle \mathrm{NADH}+\mathrm{FMN}+0.2 \mathrm{ml} \mathrm{NADH}$-dehydrogenase preparation $+\mathrm{BSA}, \mathrm{H}_{2} \mathrm{O}_{2}$ added at 43 min.

\section{2. $\mathrm{FMNH}_{2}$}

Our method measures the rate of disappearance of FMN in the presence of $\mathrm{N}_{2}$ gas as $\mathrm{FMNH}_{2}$ is formed by NADH-dehydrogenase with NADH as substrate. Fig. 2 shows that $9.3 \times 10^{-3} \mathrm{M} \mathrm{H}_{2} \mathrm{O}_{2}$ instantaneously oxidizes $\mathrm{FMNH}_{2}$ and that this oxidation is transient. The addition of BSA up to $10 \mathrm{mg} \mathrm{ml}^{-1}$ buffer causes no significant change of this result.

\section{Discussion}

It has been established that bacterial luminescence is reversibly suppressed in vivo and in vitro by both X-rays and hydrogen peroxide, a product of radiation reactions in aqueous media. The transient nature of this suppression suggests that $\mathrm{X}$-rays and $\mathrm{H}_{2} \mathrm{O}_{2}$ attack an intermediate which is under continuous production by some biochemical pathway.

The results presented here show for the first time that $\mathrm{FMNH}_{2}$ under continuous production by the NADH-dehydrogenase reaction is transiently oxidized by $\mathrm{H}_{2} \mathrm{O}_{2}$ even in the presence of relatively high concentrations of 


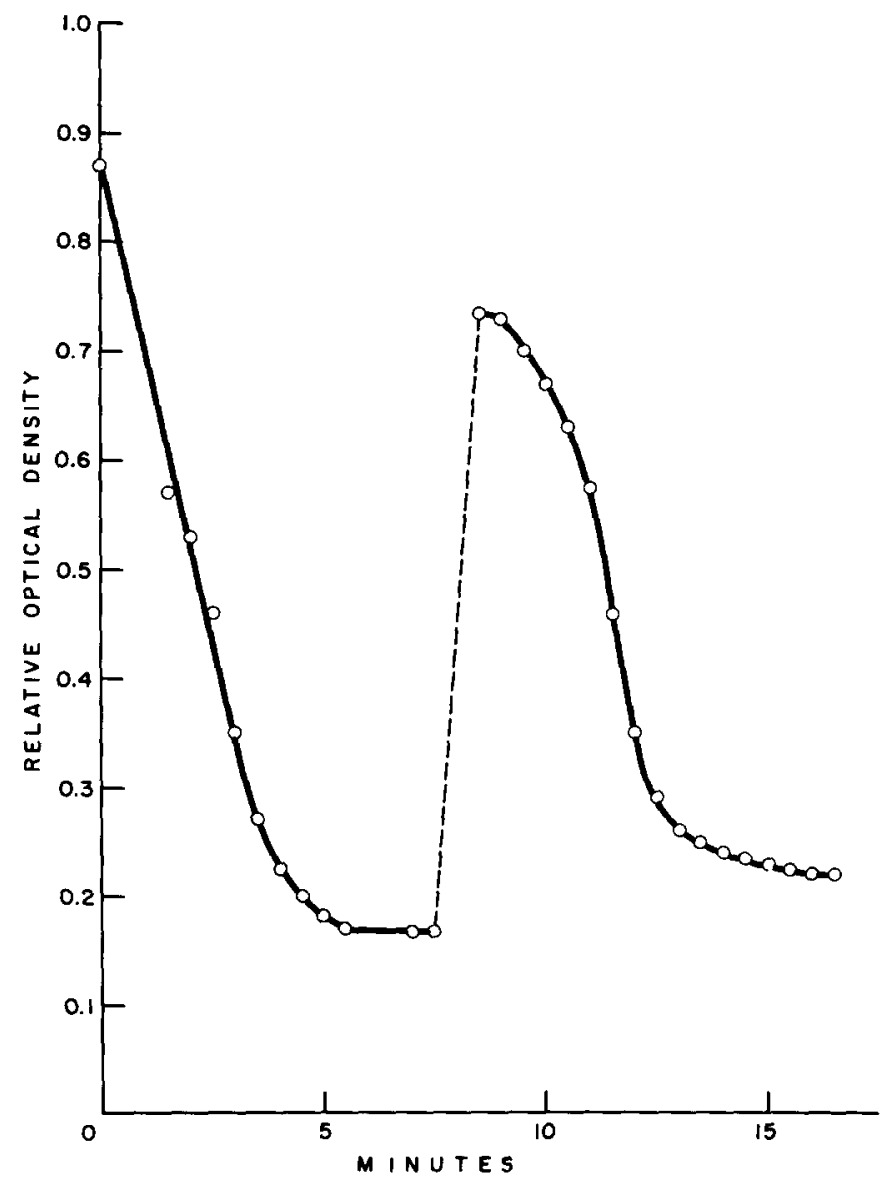

Fig. 2. The transient oxidation of reduced flavin mononucleotide by $\mathrm{H}_{2} \mathrm{O}_{2}$. The evacuated, gas-tight cuvette contained NADH + FMN $+50 \lambda \mathrm{NADH}$-dehydrogenase preparation in phosphate buffer, $\mathrm{pH} 7.5 . \mathrm{H}_{2} \mathrm{O}_{2}\left(10^{-4} \mathrm{M}\right)$ was added at $7.5 \mathrm{~min}$. The dashed portion of the curve represents the time necessary to remove the cuvette from the spectrophotometer, add $\mathrm{H}_{2} \mathrm{O}_{2}$ from one side-arm, and replace the cuvette in the sample compartment.

exogenous protein. These observations provide the basis for a mechanism which would explain the transient suppression of bacterial luminescence by $\mathrm{H}_{2} \mathrm{O}_{2}$.

The working hypothesis for this study is that steady-state luminescence is the manifestation of biochemical homeostasis that exists between the rate of production of $\mathrm{FMNH}_{2}$ by the NADH-dehydrogenase reaction and the rate of oxidation of $\mathrm{FMNH}_{2}$ by the luminescence pathway, electron transport, and autoxidation by dissolved oxygen. When this competition is increased by X-rays or $\mathrm{H}_{2} \mathrm{O}_{2}$, luminescence is suppressed in proportion to 
the amount of increased competition. Recovery of luminescence, then follows the withdrawal or depletion of this exogenous competition.

The model in fig. 3 suggests the central importance of $\mathrm{FMNH}_{2}$. In our experiments, NADH is added in large quantity while in bacterial cells it is turned over normally using a variety of substrates $\left(\mathrm{XH}_{2}\right)$. Oxidation of $\mathrm{NADH}$ by $\mathrm{H}_{2} \mathrm{O}_{2}$ in our experiments would not be recoupable since there is no mecharism for rehydrogenation of $\mathrm{NAD}^{+}$. Actually, as our results indicate, (section 4.1), NADH in the presence of even low concentrations of

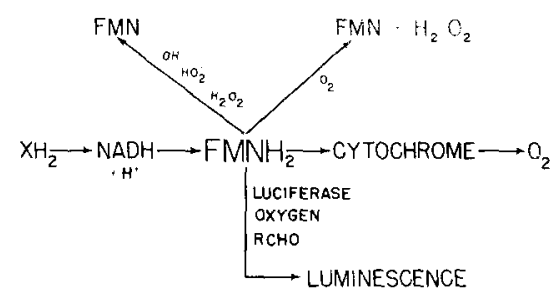

Fig. 3. The relation of various biochemical intermediates to the production of and competition for $\mathrm{FMNH}_{2}$. $\mathrm{HO} \cdot$ and $\mathrm{HO}_{2} \cdot$ represent radiation-induced free radicals.

exogenous protein (BSA) is not oxidized significantly by $\mathrm{H}_{2} \mathrm{O}_{2}$. Further, the rate of oxidation of NADH by NADH-dehydrogenase in the presence of BSA is not altered by $\mathrm{H}_{2} \mathrm{O}_{2}$. Thus, any $\mathrm{NADH}-\mathrm{H}_{2} \mathrm{O}_{2}$ reactions cannot account for the reversible peroxide suppression of bacterial luminescence.

On the other hand, the primary substrate for bacterial luciferase, $\mathrm{FMNH}_{2}$, is rapidly but only momentarily oxidized by $\mathrm{H}_{2} \mathrm{O}_{2}$ even in the presence of exogenous protein $\left(10 \mathrm{mg} \mathrm{ml}^{-1} \mathrm{BSA}\right)$. This treatment does not affect NADHdehydrogenase activity to any measurable extent (section 4.1 ).

Maximum suppression of luminescence in living cells by $\mathrm{H}_{2} \mathrm{O}_{2}$ occurs within $0.5 \mathrm{~min}^{2}$ ). Luminescence in vitro is maximally suppressed by $\mathrm{H}_{2} \mathrm{O}_{2}$ more slowly but within 1 min in most cases ${ }^{3}$ ). Our measurements of $\mathrm{FMNH}_{2}$ do not allow precise estimates of the time required for maximum oxidation by $\mathrm{H}_{2} \mathrm{O}_{2}$, but indicate that this time is compatible with the proposed mechanism (see fig. 2).

Time from $\mathrm{H}_{2} \mathrm{O}_{2}$ addition to one-half maximum recovery of luminescence in vivo varies with the concentration of peroxide, but for $3 \times 10^{-4} \mathrm{M} \mathrm{H}_{2} \mathrm{O}_{2}$ equals $5 \mathrm{~min}^{2}$ ). For recovery in vitro, this time after treatment with $3 \times 10^{-4}$ $\mathrm{M} \mathrm{H}_{2} \mathrm{O}_{2}$ is $1 \mathrm{~min}^{3}$ ). Our measurements of the recovery half-time for the $\mathrm{NADH}$-dehydrogenase production of $\mathrm{FMNH}_{2}$ is $3 \mathrm{~min}$. Thus, in spite of several variables, the recovery of initial concentrations of $\mathrm{FMNH}_{2}$ as measured spectrophotometrically is compatible with the observations of recovery of luminescence after $\mathrm{H}_{2} \mathrm{O}_{2}$ addition to luminescent systems in vivo and in vitro and thus compatible with the proposed mechanism. 
We conclude that radiomimetic effects of $\mathrm{H}_{2} \mathrm{O}_{2}$ do occur provided measurements are made on appropriate systems continuously or with a minimum of interruption since some of these effects are reversible within minutes. We also conclude that the reversible suppression of bacterial luminescence is due to the momentary oxidation of $\mathrm{FMNH}_{2}$ by $\mathrm{H}_{2} \mathrm{O}_{2}$. Further, peroxide causes no significant change of NADH or NADH-dehydrogenase activity provided protein is present.

Previous data ${ }^{4}$ ) show that the X-ray-induced suppression of bacterial luminescence is prevented by catalase. This observation very strongly implicates $\mathrm{H}_{2} \mathrm{O}_{2}$ as an important part of the mechanism which is responsible for this radiation effect. We are exploring this hypothesis.

\section{Acknowledgement}

The critical review of Harry Pettengill and Dr. Robert Kaman is acknowledged and appreciated.

\section{References}

1) H. I. Adler, Radiation Res. 3 (1963) 110

2) E. S. Guzman Barron et al., Arch. Biochem. Biophys. 41 (1952) 188.

3) C. H. Burns, A. P. Jacobson and G. H. Whipple, Radiation Res. 24 (1965) 494.

4) A. P. Jacobson, J. Luminescence 3 (1970) 203.

5) A. P. Jacobson and K. A. McDermott, J. Luminescence 3 (1971) 419.

6) A. P. Jacobson and L. R. Papa, An in vivo and in vitro comparison of the radiomimetic effects of $\mathrm{H}_{2} \mathrm{O}_{2}$ on bacterial luminescence. In preparation (1972), School of Public Health, Ann Arbor.

7) W. D. McElroy and H. H. Seliger, Adv. Enzymol. 25 (1963) 119.

8) J. W. Hastings, W. H. Riley and J. Massa, J. Biol. Chem. 240 (1965) 1473.

9) A. Eberhard and J. W. Hastings, Biochem. and Biophys. Res. Commun. 47, No. 2 (1972) 248.

10) J. W. Hastings and Q. H. Gibson, J. Biol. Chem. 238, No. 7 (1963) 2537.

11) C. H. Burns, A. D. Nevill and G. H. Whipple, Sci. 135 (1962) 431.

12) This work is included in Brendel's doctoral dissertation on microfilm, Univ. of Michigan, Ann Arbor, Michigan 48104. Title: Purification, Characterization, and $\mathrm{X}$-irradiation studies of NADH-dehydrogenase from Photobacterium fischeri. It will be published separately in 1973 .

13) I. M. Kolthoff, Quantitative Chemical Analysis, 4th ed. (MacMillan, New York 1969) p. 834. 